\title{
Are There Learning Spillovers in Introductory Macroeconomics?
}

\author{
Ross Guest and Nerina Vecchio
}

\section{Abstract}

This study examines the effect on learning outcomes for given topics in macroeconomics of conflating a twosemester micro and macroeconomics course into a one-semester combined micro/macro course by dropping some topics. A hypothesis that learning spillovers exist between topics is developed and tested. This is done by comparing examination results on a given set of multiple-choice questions for two large groups of students - one who had undertaken a single-semester course in macroeconomics and another who had undertaken a singlesemester combined micro/macroeconomics course. In our sample, the latter group of students scored significantly less on average than the former group, after controlling for other factors, even though both had 'learned' the same topics that were examined. This suggests that positive learning spillovers do exist between topics and therefore that dropping some topics reduces the quality of learning outcomes on other topics. This has implications for the apparent trend towards reducing the mandatory number of economics units in business degrees in Australia from two to one.

JEL Classification: A22

\section{Introduction}

The purpose of this study is to estimate the effect on student learning outcomes of conflating the study of introductory microeconomics and macroeconomics from a two-semester course to a one-semester course. 1 In recent years this has occurred in a number of Australian universities, typically in business degree programmes (see Table 1). This change has occurred during a period when the minimum accreditation requirements of one of the two major accounting bodies, $\mathrm{CPA}_{2}^{2}$ Australia, have been reduced from two economics units to one. This change reflects its new philosophy of encouraging more broadly educated accounting graduates by freeing up the accounting major to allow students to take more electives. This has meant reducing the number of mandatory units of study and economics has been one of the resulting casualties.

The change was announced in 1996 to take effect from 2000. The new accreditation requirements made it easy for other business disciplines, in some institutions, to push for the conflating of the two single-semester units of introductory economics into a one-semester combined micro and macroeconomics unit. The ability of the other business disciplines to mount political pressure to effect this change has been facilitated by relatively poor student satisfaction in economics, evidenced by both low CEQ scores (Guest and Duhs, 2001) and a trend of declining enrolments over the past two decades (Milmow, 1997).

\section{Table 1 University business degrees with either a one-semester combined macro/ microeconomics course or a full semester of macroeconomics and microeconomics, Australia, 2001}




\begin{tabular}{|c|c|c|c|c|c|c|c|}
\hline & University & $\begin{array}{l}\text { Subject } \\
\text { structure }\end{array}$ & $\begin{array}{c}\text { Restructured } \\
\quad(\text { yes } / \text { no })\end{array}$ & $\begin{array}{c}\text { Reason } \\
\text { (why } \\
\text { restructured) }\end{array}$ & $\begin{array}{c}\text { Year } \\
\text { restructured }\end{array}$ & $\begin{array}{l}\text { Restructuring } \\
\text { in the future } \\
\quad(\text { yes/no })\end{array}$ & $\begin{array}{c}\text { Reason } \\
\text { (why not) }\end{array}$ \\
\hline & \multicolumn{7}{|c|}{ New South Wales } \\
\hline 1 & $\begin{array}{l}\text { Australian } \\
\text { National } \\
\text { University }\end{array}$ & Combined & Yes & Trend & 1996 & & \\
\hline 2 & $\begin{array}{l}\text { University } \\
\text { of Canberra }\end{array}$ & & & & & & \\
\hline 3 & $\begin{array}{l}\text { Avondale } \\
\text { College }\end{array}$ & $\mathrm{S} 1 / 2$ & No & & & No & Not suitable \\
\hline 4 & $\begin{array}{l}\text { Charles } \\
\text { Sturt } \\
\text { University }\end{array}$ & $\mathrm{S} 1 / 2$ & No & & & No & $\begin{array}{l}\text { Never } \\
\text { considered }\end{array}$ \\
\hline 5 & $\begin{array}{l}\text { Macquarie } \\
\text { University }\end{array}$ & Combined & Yes & & & & \\
\hline 6 & $\begin{array}{l}\text { Southern } \\
\text { Cross } \\
\text { University }\end{array}$ & $\mathrm{S} 1 / 2$ & No & & & No & Not suitable \\
\hline 7 & $\begin{array}{l}\text { University } \\
\text { of New } \\
\text { England }\end{array}$ & $\mathrm{S} 1 / 2$ & No & & & No & Not suitable \\
\hline 8 & $\begin{array}{l}\text { University } \\
\text { of New } \\
\text { South } \\
\text { Wales }\end{array}$ & $\mathrm{S} 1 / 2$ & No & & & No & Not suitable \\
\hline 9 & $\begin{array}{l}\text { University } \\
\text { of } \\
\text { Newcastle }\end{array}$ & $\mathrm{S} 1 / 2$ & No & & & No & Not suitable \\
\hline 10 & $\begin{array}{l}\text { University } \\
\text { of Sydney }\end{array}$ & $\mathrm{S} 1 / 2$ & No & & & No & $\begin{array}{l}\text { Previously } \\
\text { combined }\end{array}$ \\
\hline 11 & $\begin{array}{l}\text { University } \\
\text { of } \\
\text { Technology }\end{array}$ & Combined & Yes & $\begin{array}{l}\text { Loss of } \\
\text { interest and } \\
\text { decreasing } \\
\text { student } \\
\text { numbers }\end{array}$ & 2001 & & \\
\hline
\end{tabular}




\begin{tabular}{|c|c|c|c|c|c|c|c|}
\hline 12 & $\begin{array}{l}\text { University } \\
\text { of Western } \\
\text { Sydney }\end{array}$ & & & & & & \\
\hline \multirow[t]{3}{*}{13} & $\begin{array}{l}\text { University } \\
\text { of } \\
\text { Wollongong }\end{array}$ & $\mathrm{S} 1 / 2$ & No & & & Yes & Under review \\
\hline & University & \begin{tabular}{|l} 
Subject \\
structure
\end{tabular} & $\begin{array}{l}\text { Restructured } \\
\quad(\text { yes/no })\end{array}$ & $\begin{array}{c}\begin{array}{c}\text { Reason } \\
\text { (why } \\
\text { restructured) }\end{array}\end{array}$ & $\begin{array}{c}\text { Year } \\
\text { restructured }\end{array}$ & $\begin{array}{l}\text { Restructuring } \\
\text { in the future } \\
\text { (yes/no) }\end{array}$ & $\begin{array}{c}\text { Reason } \\
\text { (why not) }\end{array}$ \\
\hline & \multicolumn{7}{|c|}{ Northern Territory } \\
\hline 14 & \begin{tabular}{|l|} 
Northern \\
Territory \\
University
\end{tabular} & Combined & Yes & \begin{tabular}{|l|} 
Loss of \\
interest and \\
decreasing \\
student \\
numbers
\end{tabular} & $1997-8$ & & \\
\hline 15 & \begin{tabular}{|l|} 
Batchelor \\
College
\end{tabular} & & & & & & \\
\hline \multicolumn{8}{|c|}{ Queensland } \\
\hline 16 & \begin{tabular}{|l} 
Bond \\
University
\end{tabular} & $\mathrm{S} 1 / 2$ & No & & & No & $\begin{array}{l}\text { Majors in } \\
\text { both micro } \\
\text { and macro }\end{array}$ \\
\hline 17 & $\begin{array}{l}\text { Central } \\
\text { Queensland } \\
\text { University }\end{array}$ & Combined & Yes & $\begin{array}{l}\text { Loss of } \\
\text { interest and } \\
\text { decreasing } \\
\text { student } \\
\text { numbers }\end{array}$ & 2000 & & \\
\hline 18 & \begin{tabular}{|l|} 
Griffith \\
University
\end{tabular} & Combined & Yes & $\begin{array}{l}\text { Management } \\
\text { policy }\end{array}$ & 2000 & & \\
\hline 19 & $\begin{array}{l}\text { James Cook } \\
\text { University }\end{array}$ & & & & & & \\
\hline 20 & $\begin{array}{l}\text { University } \\
\text { of } \\
\text { Queensland }\end{array}$ & $\mathrm{S} 1 / 2$ & No & & & No & $\begin{array}{l}\text { Undergraduate } \\
\text { kept separate } \\
\text { - majors in } \\
\text { macro and } \\
\text { micro }\end{array}$ \\
\hline 21 & $\begin{array}{l}\text { Queensland } \\
\text { University } \\
\text { of } \\
\text { Technology }\end{array}$ & Combined & Yes & Trend & 1996 & & \\
\hline
\end{tabular}




\begin{tabular}{|c|c|c|c|c|c|c|c|}
\hline 22 & $\begin{array}{l}\text { University } \\
\text { of Southern } \\
\text { Queensland }\end{array}$ & Combined & No & Always been & & No & $\begin{array}{l}\text { Core subject } \\
\text { for all } \\
\text { bachelor of } \\
\text { business } \\
\text { students }\end{array}$ \\
\hline & \multicolumn{7}{|c|}{ South Australia } \\
\hline 23 & $\begin{array}{l}\text { University } \\
\text { of Adelaide }\end{array}$ & $\mathrm{S} 1 / 2$ & No & & & No & $\begin{array}{l}\text { Majors in } \\
\text { economics, } \\
\text { commerce } \\
\text { and finance }\end{array}$ \\
\hline 24 & $\begin{array}{l}\text { Flinders } \\
\text { University } \\
\text { of South } \\
\text { Australia }\end{array}$ & $\mathrm{S} 1 / 2$ & No & & & No & $\begin{array}{l}\text { Previously } \\
\text { combined; did } \\
\text { not work out }\end{array}$ \\
\hline \multirow[t]{3}{*}{25} & $\begin{array}{l}\text { University } \\
\text { of South } \\
\text { Australia }\end{array}$ & & & & & & \\
\hline & University & $\begin{array}{l}\text { Subject } \\
\text { structure }\end{array}$ & $\begin{array}{c}\text { Restructured } \\
\quad(\text { yes/no })\end{array}$ & $\begin{array}{c}\text { Reason } \\
\text { (why } \\
\text { restructured) }\end{array}$ & $\begin{array}{c}\text { Year } \\
\text { restructured }\end{array}$ & $\begin{array}{l}\text { Restructuring } \\
\text { in the future } \\
\text { (yes/no) }\end{array}$ & $\begin{array}{l}\text { Reason } \\
\text { (why not) }\end{array}$ \\
\hline & \multicolumn{7}{|c|}{ Tasmania } \\
\hline 26 & $\begin{array}{l}\text { University } \\
\text { of } \\
\text { Tasmania }\end{array}$ & Combined & Yes & $\begin{array}{l}\text { Management } \\
\text { and policies }\end{array}$ & 1998 & & \\
\hline \multicolumn{8}{|c|}{ Victoria } \\
\hline 27 & $\begin{array}{l}\text { Deakin } \\
\text { University }\end{array}$ & $\mathrm{S} 1 / 2$ & No & & & No & \\
\hline 28 & $\begin{array}{l}\text { La Trobe } \\
\text { University }\end{array}$ & & & & & & \\
\hline 29 & $\begin{array}{l}\text { Monash } \\
\text { University }\end{array}$ & $\mathrm{S} 1 / 2$ & No & & & No & $\begin{array}{l}\text { Too } \\
\text { complicated } \\
\text { to combine }\end{array}$ \\
\hline 30 & $\begin{array}{l}\text { Royal } \\
\text { Melbourne } \\
\text { Institute of } \\
\text { Technology }\end{array}$ & $\mathrm{S} 1 / 2$ & No & $\begin{array}{l}\text { Maintain } \\
\text { traditional } \\
\text { form }\end{array}$ & No & & \\
\hline
\end{tabular}




\begin{tabular}{|c|c|c|c|c|c|c|c|}
\hline 31 & $\begin{array}{l}\text { Swinburne } \\
\text { University } \\
\text { of } \\
\text { Technology }\end{array}$ & & & & & & \\
\hline 32 & $\begin{array}{l}\text { University } \\
\text { of Ballarat }\end{array}$ & $\mathrm{S} 1 / 2$ & No & & & No & $\begin{array}{l}\text { Economic } \\
\text { majors under } \\
\text { review }\end{array}$ \\
\hline 33 & $\begin{array}{l}\text { University } \\
\text { of } \\
\text { Melbourne }\end{array}$ & & & & & & \\
\hline 34 & $\begin{array}{l}\text { Victoria } \\
\text { University } \\
\text { of } \\
\text { Technology }\end{array}$ & $\mathrm{S} 1 / 2$ & No & & & No & Not suitable \\
\hline 35 & $\begin{array}{l}\text { Marcus } \\
\text { Oldham } \\
\text { College }\end{array}$ & $\mathrm{S} 1 / 2$ & No & & & & \\
\hline & University & $\begin{array}{l}\text { Subject } \\
\text { structure }\end{array}$ & $\begin{array}{c}\text { Restructured } \\
\text { (yes/no) }\end{array}$ & $\begin{array}{c}\text { Reason } \\
\text { (why } \\
\text { restructured) }\end{array}$ & $\begin{array}{c}\text { Year } \\
\text { restructured }\end{array}$ & $\begin{array}{l}\text { Restructuring } \\
\text { in the future } \\
\quad(\text { yes/no })\end{array}$ & $\begin{array}{l}\text { Reason } \\
\text { (why not) }\end{array}$ \\
\hline & \multicolumn{7}{|c|}{ Western Australia } \\
\hline 36 & $\begin{array}{l}\text { Curtin } \\
\text { University } \\
\text { of } \\
\text { Technology }\end{array}$ & $\mathrm{S} 1 / 2$ & No & - & - & No & Not suitable \\
\hline 37 & $\begin{array}{l}\text { Edith } \\
\text { Cowan } \\
\text { University }\end{array}$ & Combined & Yes & Trend & $1995-6$ & & \\
\hline 38 & $\begin{array}{l}\text { Murdoch } \\
\text { University }\end{array}$ & $\mathrm{S} 1 / 2$ & No & - & - & No & $\begin{array}{l}\text { Because of } \\
\text { majors, micro } \\
\text { and macro } \\
\text { kept separate }\end{array}$ \\
\hline 39 & $\begin{array}{l}\text { University } \\
\text { of Notre } \\
\text { Dame }\end{array}$ & Combined & Yes & $\begin{array}{l}\text { For all } \\
\text { undergraduate } \\
\text { bachelor of } \\
\text { business } \\
\text { students }\end{array}$ & 1994 & & \\
\hline
\end{tabular}




\begin{tabular}{|l|l|l|l|l|l|l|}
\hline $\mathbf{4 0}$ & $\begin{array}{l}\text { Australian } \\
\text { Catholic } \\
\text { University }\end{array}$ & S1/2 No & No & \\
\hline
\end{tabular}

The question in this study is not whether total learning outcomes in economics are less with a one-semester course than with a two-semester course. Clearly they would be because fewer topics are covered in the one-semester course and less time may be spent on each topic. It is a well-supported principle from the theoretical and empirical literature (not to mention blindingly obvious common sense) that quality-adjusted learning outcomes are a positive function of 'time on task' - that is, the time that the student spends actively engaged with learning tasks. See, for example, Ramsden (1992, p. 81) and, for a recent empirical study, Aksoy and Link (2000). The question here is a little subtler. It is whether there are spillovers to learning outcomes in other topics in introductory economics arising from the teaching and learning of a given topic. If this were the case, then dropping topics to accommodate a shorter period of study would reduce the quality of learning outcomes in those topics that were retained even if the same learning time were allocated to them.

Whether such externalities exist in teaching and learning of topics in any discipline must depend on how closely the topics are related - what fundamental concepts, methods of analysis and ways of understanding are common to all of the topics. Such associations surely exist to some extent across all disciplines, but to varying degrees. The purpose here is to find out to what extent they exist in introductory economics. We test this by estimating the effect on student achievement in particular topics of the removal of other topics associated with the compression of the scope of introductory economics from a two-semester to a one-semester course, holding all other aspects of the learning environment constant.

The remainder of the paper is organised as follows. The next section examines learning in introductory economics and the nature of the spillovers that exist in particular learning units. The third section describes a very simple model of learning spillovers. The fourth section describes the data and methodology used to test the proposition that spillovers do exist and that learning outcomes in particular topics are therefore lower as a result of eliminating other topics. The fifth section explains the results and the sixth section concludes the paper with some implications for professional bodies accrediting business degrees.

\section{Learning in introductory economics}

Our aim in teaching a first-year Principles course is to teach for student understanding of fundamental economic principles. But what level of 'understanding' are we aiming for? The various levels of understanding can be described by the SOLO taxonomy (structure of learning outcomes), in ascending order of cognitive complexity as follows (Biggs, 1999, p. 47; Prosser and Trigwell, 1999, p.119):

- Prestructural - the student misses the point.

- Unistructural - the student can identify a single point or aspect of an argument or do a simple procedure.

- Multistructural - the student can list several relevant points or aspects of an argument or do a string of related procedures.

- Relational - the student can integrate relevant points into a structure and can therefore explain causes, analyse, relate and apply.

- Extended abstract - the student can generalise understanding to a new domain: that is, reflect, hypothesise and theorise. 
Most of us would agree that it is unrealistic to expect the extended abstract from most students. We tend to aim for the relational level of cognitive complexity. This is the level at which students can begin to 'think like an economist'. The next question is: how can we facilitate students getting to this level? The trick is to get students to make connections between economic concepts and topics. For example, in teaching macroeconomics we might want students to connect at least four markets: the market for aggregate goods and services, the labour market, the market for foreign currency and the money market. We would want them to see how the prices in these four markets are related: that is, the general price level, the real wage, the exchange rate and the interest rate. It is the ability to show interconnections between the markets in response to a given scenario that indicates the relational level of understanding. An example might be the ability to explain a short-run Phillips curve story, given a scenario of a tax cut in the face of cyclical unemployment, showing the effect on all four markets, including second-round feedback effects. We would generally go about achieving this level of understanding by starting with one topic (typically the market for aggregate goods and services) and then proceeding to other topics one at a time, building up the interconnections as we go. These markets are like four pillars of a macroeconomic building. If we remove one of the four markets, or don't construct the building properly, it tends to collapse along with student understanding.

This is the danger in the conflated one-semester version of the macro/micro principles course. Once we start leaving out or skimming over topics that are fundamental building blocks, which we must inevitably do, we weaken the level of understanding of other topics. This can occur even if we spend exactly the same learning time and use the same methods in teaching the other topics. The reason is that many of the introductory topics in economics are mutually reinforcing and help students to understand the whole structure. An understanding of the structure in turn reinforces understanding of the building blocks. Hence topics A, B and C reinforce understanding of topic D. So if topic B or C is omitted, the understanding in topic D will be diminished. At a more fundamental level, the economic way of thinking runs through all topics; and the principle of mutual reinforcement extends to the basic tools of analysis and underlying concepts. These include the use of two-dimensional diagrams, costs versus benefits, opportunity cost, the consumer, the firm, economic welfare and the goals of government policy.

This principle of mutual reinforcement - of concepts, topics and methods of analysis that are different yet share some common foundations - is well established in the literature on learning. In his book on modelling learning in economics, Brenner (1999, pp. 22-46) draws on the literature in cognitive psychology in categorising cognitive learning processes as either associative or routine-based learning. In both types of learning, individuals develop learning rules based on recognition of past situations and the reapplication of learning rules that have produced satisfying results in the past. The difference between the two models is that in associative learning the learning rule is adapted to meet changed circumstances before it is applied, which is a time-consuming process. On the other hand, in routine learning the model is routinely applied to similar circumstances and only subsequently adjusted if the results are not satisfactory. The important point for the present discussion is that both types of cognitive model are stabilised by reinforcing results. The resulting stable model may be optimal in the utility-maximising sense if the individual has a realistic model and enough information (Brenner, 1995, p. 45). There is a gain in time in reaching the stable learning rule faster. This gain in time may allow other learning outcomes to be achieved.

For example, suppose that a student has learned that unemployment can be understood in terms of excess supply in the labour market due to real wages being above their equilibrium level; and that this can be illustrated in a diagram. The student is then faced with the capital market for a small open economy such as Australia, the learning objective being to understand and illustrate on a diagram Australia's current account deficit in terms of excess demand for capital - national investment exceeding national saving - at the prevailing world interest rate. This requires an understanding of how to read off the quantity of capital demanded and supplied and how to interpret the difference between the two as either a surplus or a deficit. A routine-based learner might start at a price above 
equilibrium, as in the case of unemployment, draw (or imagine) a horizontal line from the vertical axis and find the perpendiculars at the points of contact with the demand and supply curves respectively. The result, however, would be a current account surplus rather than a deficit. This unsuccessful result would lead to another trial, this time with the price below the equilibrium and with successful results. The learning rule would be extended accordingly. The associative learner would think about the difference between the two situations in order to find the correct outcome in the first instance. However, the important point here is that, in both cases, learning has been facilitated by a previous related problem. Subsequently, when both students are faced with the problem of understanding an exchange rate depreciation, they will have benefited from their engagement with the method of understanding unemployment and current account deficits. If, however, one topic is removed from the course - say, unemployment - in conflating the two-semester into a one-semester course, the quality of understanding of other topics such as exchange rate determination and the current account is diminished.

Students' prior experiences and related conceptual understanding influence their approach to new learning situations, which in turn affects their learning outcomes (Prosser and Trigwell, 1999). Students with a betterdeveloped prior conceptual understanding are more likely to adopt a 'deep' approach to learning and therefore to achieve better learning outcomes than students with a less developed prior understanding. Briefly, in the deep approach students aim to understand ideas and relationships and seek new meanings for themselves, while in the surface approach students focus on what they need to do to pass assessment tasks with minimum effort, which leads to separate treatment of related principles and rote learning. Learning outcomes are maximised with a deep approach rather than a surface approach. To illustrate in terms of the above example, macroeconomics students approaching the study of the market for foreign exchange without having engaged with problems in the labour market or capital market are more likely to take a surface approach to the problem. In contrast, students with prior understanding of the labour market or capital market are more likely to wonder whether the foreign exchange market works in the same way and hence to seek deeper understanding. $\underline{3}$

Whether the student adopts a surface or deep approach to learning depends not only on their prior experience but also on their personal characteristics. This is based on the accepted 3P model of teaching and learning, consisting of presage, process, product (Biggs, 1999, p. 18; Prosser and Trigwell, 1999, p. 12). Differences among student learning at the presage stage can be expected to impact on the approach to learning (the process) which in turn affects student learning outcomes (the product). Hence, the impact of the cut-down one semester course in economics on understanding of any given topic may depend on the characteristics of the student. Bacdayan (1997) estimated a production function of individual learning in economics and concluded that several personal characteristics of students significantly affected achievement.

In this study we attempt to control for both the student's prior experience with economics and some of their personal characteristics. For example, we identify those students from the one-semester macroeconomics course or the conflated micro/macro course who have taken microeconomics before. We control for the following student characteristics, for which we have readily available data: the student's general academic ability proxied by their university entry score, 4 the 'major' undertaken by students within the bachelor of business, age, enrolment status (part time or full time) and gender. We aim to control for as many other aspects of the two Ps, presage and process, as possible. For example, the teaching methods and assessment types are held constant, as are the textbook, teaching personnel and physical learning environment (same campus and teaching facilities).

\section{A simple model of learning spillovers between topics}

Becker (1982) models learning in a given subject, such as economics, as depending not just on time spent learning 
economics, but also on time spent learning complementary subjects such as mathematics. He adopts a linear model of this learning production process, described for the simple case of only two subjects as:

$$
\mathrm{L}_{\mathrm{i}}=\sum_{\mathrm{j}=1}^{2} \mathrm{a}_{\mathrm{ij}} \mathrm{T}_{\mathrm{j}}, \mathrm{i}=1,2
$$

where $L_{i}$ is learning outcomes in subject i, $T_{j}$ is jth subject study time and $a_{i j}$ is a technology coefficient for a fixed student intelligence quotient and teaching method, where $a_{i i}>a_{i j}>0$. The model of learning underlying the estimating model in this paper is related to Becker's model, the main difference being that $j$ and $i$ are topics in a single subject, economics, rather than different subjects. In this study, the value of $a_{i j} T_{j}$ is described as the learning spillovers for topic $i$ as a result of time spent learning topic $j$. We posit the following form of the model:

$$
L_{i k}=\gamma_{k}+\sum_{j=1}^{n} a_{i j} T_{j}, i=1, \ldots, n
$$

where $n$ is the number of topics in macroeconomics in a particular course, $\gamma_{k}$ is a vector of the prior skills, experiences, knowledge and personal characteristics of student $\mathrm{k}$ and $a_{i j}$ is a coefficient determined by all aspects of the learning environment. In our empirical study we held as many aspects of the learning environment as possible constant across both types of course. These include: the textbook and chapters in the textbook chosen for study; the duration of class time spent teaching each topic; the nature of the presentation of each topic to students, including the lecture; the teaching staff; and the lecture venue and classrooms. Some change in the approach to teaching certain topics is inevitable in moving from the full-semester course in macroeconomics to what is effectively a half-semester course. For example, the approach to teaching unemployment may depend on whether the economics of labour markets has been taught. We made only those changes in approach that were appropriate to account for the shorter course.

We assume that $T_{j}$ is the same for students in both courses on average. Consistent with this assumption, in our study we held the class time spent on each topic constant across both types of course. For instance, if a given topic received one lecture and one tutorial in the one-semester course, it received the same treatment in the conflated course. The assumption further implies that students in each course spend the same time in private study on average. $\underline{5}$
We hypothesise that learning spillovers do exist and are positive: that is, $\sum_{j=1}^{n} a_{i j}>0, i \neq j$. This implies that, because the number of topics ( $n$ ) in macroeconomics is less in the conflated course, $L_{i}$ is also less for students on average in the conflated course. Hence our testable hypothesis is that average scores are lower for the conflated course, controlling for some personal characteristics of students. 


\section{Data and regression model}

We compared the scores of the students in the full-semester macroeconomics course with those of students in the conflated course. To do this we chose 40 multiple-choice questions that were common to the examinations in both courses. These consisted of 14 multiple-choice questions from the mid-semester and 26 multiple-choice questions from the final examination of the full-semester macroeconomics course to derive a set of 40 multiple-choice questions for the final examination of the conflated course. The 40 multiple-choice questions are reproduced in Appendix 1.

The Planning and Statistics Unit at Griffith University provided data on students' university entry score, $\underline{6}$ course, age, enrolment status and gender, in order to control for students' personal characteristics that might affect their learning outcomes. We also controlled for students who had taken prior economics courses. There are two cases here. One is where students enrolled in the full-semester macro course have previously taken a micro course. The other is where students in the combined course have previously taken either a one-semester micro or macro course. Business students who have already taken a course in either micro or macro (but not both) are effectively required to repeat, for half a semester, the coursework that they have already done. The reason is that they have only completed half of the coursework in the conflated course and are therefore not entitled to credit for the whole course. As our 40 multiple-choice questions are all macro questions, it is especially important to control for students enrolled in the combined course who have already taken a one-semester course in macro, because they are effectively repeating the macro part of the combined course. Therefore those students could appear in both samples that we are comparing. For this reason, we decided to remove this group of students from our data set. We controlled for students who had previously taken a micro course by adding a dummy variable to the regression as described below, in order to test whether spillovers exist from microeconomics to macroeconomics.

We ran the following linear regression model with the percentage achievement score as the dependent variable:

$$
S_{i}=\alpha_{0}+\alpha_{1} O_{i}+\alpha_{2} T_{i}+\alpha_{3} P_{i}+\alpha_{4} W_{i}+\alpha_{5} G_{i}+\alpha_{6} A_{i}+\alpha_{7} M_{i}+\varepsilon_{i}
$$

where

$\mathrm{S}=$ the student's percentage score on the 40 multiple-choice questions

$\mathrm{O}=$ the $\mathrm{OP}$ score as a continuous variable

$\mathrm{T}=1$ if the student did the conflated (macro/micro) course; 0 if the student did the full-semester macroeconomics course

$\mathrm{P}=1$ if the student was taking the subject as an elective; 0 if the student was taking the business programme

$\mathrm{W}=1$ if the student was part time; 0 if the student was full time

$\mathrm{G}=1$ if the student was male; 0 if the student was female

$\mathrm{A}=1$ if the student was a mature-age student (over 25 years of age); 0 if the student was 25 or under 
$\mathrm{M}=1$ if the student had previously undertaken microeconomics; 0 for others

If learning spillovers exist then the parameter estimate on $T$ will be significantly negative. Hence the null hypothesis is $H_{0}: \alpha_{7}=0 ; H_{1}: \alpha_{7}<0$. A subsidiary hypothesis is that learning spillovers exist from microeconomics to macroeconomics. The null hypothesis for this test is $H_{0}: \alpha_{7}=0 ; H_{1}: \alpha_{7}>0$.

\section{The results}

The mean overall achievement score for the 320 students who undertook the one-semester macro course was 64.5 per cent, compared with 61.3 per cent for the 342 students in the conflated course (see Table 2). The difference is significant at 1 per cent.

\section{Table 2 Descriptive statistics}

\begin{tabular}{|c|c|c|c|c|c|c|c|}
\hline & \multicolumn{3}{|c|}{$\begin{array}{l}\text { Macroeconomics } \\
(n=320)\end{array}$} & \multicolumn{3}{|c|}{$\begin{array}{l}\text { Combined course } \\
(n=342)\end{array}$} & \multirow[t]{2}{*}{$\begin{array}{l}p \text { - } \\
\text { value } 7\end{array}$} \\
\hline & Mean & SD & $(\%)$ & Mean & SD & $(\%)$ & \\
\hline $\begin{array}{l}\text { Dependent variable } \\
\text { Student scores out of } 40\end{array}$ & 25.8 & 4.94 & 64.5 & 24.5 & 5.51 & 61.3 & $0.002 * *$ \\
\hline \multicolumn{8}{|l|}{$\begin{array}{l}\text { Student characteristics } \\
\text { (independent variables) }\end{array}$} \\
\hline Core subject (i.e. non-elective) & & & 64.1 & & & 66.5 & 0.36 \\
\hline Full-time student & & & 90.6 & & & 87.4 & 0.23 \\
\hline Mature age $(+25 \mathrm{yrs})$ & & & 16.9 & & & 13.5 & 0.25 \\
\hline Male & & & 42.8 & & & 41.2 & 0.41 \\
\hline Previously undertook micro & & & 10.3 & & & 17.5 & $0.07 *$ \\
\hline OP scores & 9.5 & & & 10.4 & & & $0.001 * *$ \\
\hline
\end{tabular}

Source: Griffith University Student Information, 2001.

* Significant at 0.05 level (two-tailed). ** Significant at 0.01 level (two-tailed).

The regression model (3) is an attempt to test whether this difference is attributable to the differences in the two courses rather than to differences in those student characteristics for which data were available. Table 3 presents the parameter estimates from (3). The estimate of $\alpha_{2}$ is significantly negative at 5 per cent, providing support for the hypothesis that learning spillovers exist. Also, if the student had previously done microeconomics, their results on the test questions (which were all macroeconomics questions) were significantly higher at 5 per cent. Again this supports the idea of learning spillovers from some, in this case micro, topics to other topics. In fact, as indicated by 
the unstandardised coefficients, the latter effect is larger in magnitude. For example, having done micro increases the test score by 5.9 percentage points on average; whereas the effect of dropping some topics in macro, in order to achieve the conflated micro/macro course, reduces the test score by 2.3 percentage points on average.

\section{Table 3 Regression results}

$$
S_{i}=\alpha_{0}+\alpha_{1} O_{i}+\alpha_{2} T_{i}+\alpha_{3} P_{i}+\alpha_{4} W_{i}+\alpha_{5} G_{i}+\alpha_{6} A_{i}+\alpha_{7} M_{i}+\varepsilon_{i}
$$

\begin{tabular}{|l|l|l|l|}
\hline \multicolumn{1}{|l|}{} & $\begin{array}{c}\text { Unstandardised } \\
\text { coefficients }\end{array}$ & $\begin{array}{c}\text { Standardised } \\
\text { coefficients }\end{array}$ & $p$-value \\
\cline { 1 - 2 } Constant & 77.370 & 0.362 & $0.000^{* *}$ \\
\hline $\mathrm{O}$ & 1.453 & -0.087 & $0.017^{* *}$ \\
\hline $\mathrm{T}$ & -2.296 & -0.056 & 0.121 \\
\hline $\mathrm{P}$ & -1.563 & 0.094 & $0.011^{* *}$ \\
\hline $\mathrm{W}$ & 4.407 & 0.026 & 0.468 \\
\hline $\mathrm{G}$ & 0.703 & 0.037 & 0.326 \\
\hline $\mathrm{A}$ & 1.372 & 0.157 & $0.000^{* *}$ \\
\hline M & 5.908 & & \\
\hline Adj. $R^{2}$ & 0.177 & 0.000 & \\
\hline F & 20.811 & & \\
\hline
\end{tabular}

Source: Griffith University Student Information, 2001.

* Significant at 0.05 level (two-tailed). **Significant at 0.01 level (two-tailed).

Variables explained in text above.

The standardised coefficients enable a comparison to be made of the relative magnitude of the effects of variables measured in different units. The OP score is the only non-dummy variable. This has the largest effect on the test scores - in fact, double the effect of having done micro previously - and it is significant at 1 per cent. The other variable to have a significant effect on test scores is $W$, indicating that part-time students perform significantly better than full-time students, having controlled for age. This is an interesting result in itself and worthy of further investigation.

\section{Conclusion}

The particular implication from this study is that by dropping some topics in introductory macroeconomics we can expect inferior quality learning outcomes in other topics. One possible inference is that students are less likely to achieve the desired relational level of understanding of given topics when other topics are omitted. There is every 
reason to expect the same to apply in introductory microeconomics as in introductory macroeconomics, although we cannot test this with our data. We also found evidence that learning spillovers exist from microeconomics to macroeconomics.

These results have implications for professional bodies - in accounting, for example - that decide how much introductory economics is required for professional accreditation in business degrees. There has been, in Australia, a reduction in the volume of introductory economics required for accreditation by the professional accounting bodies. Perhaps they thought that the more important topics could still be taught and learned as effectively in a shorter programme of study, while dropping the less important topics. This study indicates that this logic is flawed because it does not account for the learning spillovers that exist between topics. Topics reinforce each other. By teaching and learning fewer topics the quality of learning outcomes in the remaining topics is diminished.

On the other hand, the accounting bodies and university curriculum planners may have been very well aware that there would be a cost in learning outcomes from shortening the introductory economics course. They may have judged that the advantages of broadening the curriculum, of giving students greater exposure to other fields of knowledge, were worth the loss of some understanding in economics. This goes to the fundamental question of what to include and exclude in a commerce/business curriculum. Although this is beyond the scope of our paper, our experience in Australia suggests that commerce/business curricula have not been designed with sufficient attention to best educational practice in curriculum development. Other factors have been rather too important, such as student load-sharing deals between departments and the political influence of some academic departments relative to others. An evaluation of the process of curriculum development and design in the commerce/business disciplines at university level would be a worthwhile future project.

\title{
The Appendix to this article is on a separate page.
}

\section{Contact details}

\author{
Ross Guest \\ School of Accounting and Finance \\ Griffith University \\ PMB 50 \\ Gold Coast Mail Centre \\ Queensland, 9726 \\ Australia \\ Fax: 0755948068 \\ Email: ‥Guest@mailbox.gu.edu.au
}

\section{References}

Aksoy, T. and Link, C. R. (2000) 'A panel analysis of student mathematics achievement in the US in the 1990s: does increasing the amount of time in learning activities affect math achievement?', Economics of Education Review, vol. 19, pp. 261-77.

Bacdayan, A. W. (1997) 'A mathematical analysis of the learning production process and a model for determining what matters in education', Economics of Education Review, vol. 16, no. 1, pp. 25-37. 
Becker, W.K. (1982) 'The educational process and student achievement given uncertainty in measurement', American Economic Review, vol. 72, no. 1, pp. 229-36.

Biggs, J. (1999) Teaching for Quality at University, Buckingham: Society for Research into Higher Education and Open University Press.

Brenner, T. (1999) Modelling Learning in Economics, Cheltenham: Edward Elgar.

Guest, R. and Duhs, A. (2001) 'Economics teaching in Australian universities: rewards and outcomes', mimeo, Griffith University.

Milmow, A. (1997) 'To eke out a marginal existence: economics in business schools', Economics Papers, vol. 16, no. 3, pp. 88-95.

Prosser, M and Trigwell, K. (1999) Understanding Learning and Teaching: The Experience in Higher Education, Buckingham: Society for Research into Higher Education and Open University Press.

Ramsden, P. and Moses, I. (1992) 'Associations between research and teaching in Australian Higher Education', Higher Education, vol. 23, no. 3, pp. 273-95.

Ramsden, P (1992) Learning to teach in higher education, London: Routledge

\section{Notes}

[1] In this paper a course is defined as a one-semester programme of study amounting to approximately 13 weeks, consisting of 3 hours of classes each week.

[2] Certified practising accountants.

[3] The process by which students create meaning for themselves based on their prior understandings is described by the learning theory of 'constructivism'.

[4] Students entering from secondary school in Queensland, Australia, are given an entry score called an 'OP score'. Students entering through other pathways, such as relevant work experience and prior tertiary study, are typically given a ranking that is converted into an equivalent OP score. However, we did not have an OP score for some students in our sample due to a range of glitches in the administrative system, so we removed these students from our data set.

[5] Of course, study effort varies greatly among students. However, given the large numbers of students in each course (320 and 342) the assumption that the average study time of students in each sample is equal seems reasonable.

[6] The standard university entry score in Queensland, Australia, is the 'OP score'. 
[7] $P$-value for test of the null hypothesis that the scores are drawn from the same population. 